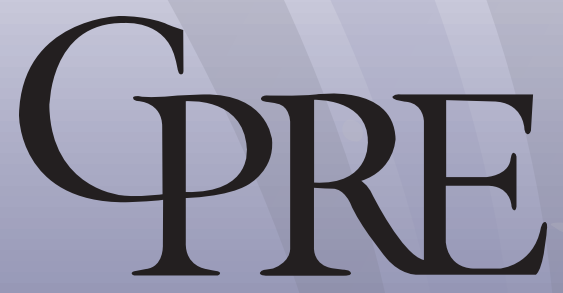

\title{
Building a Lattice for School Leadership: \\ The Top-to-Bottom Rethinking of Leadership Development in England and What It Might Mean for American Education
}

\section{JONATHAN SUPOVITZ}

with foreword by Andy Hargreaves 
Suggested Citation:

Supovitz, J. (2014). Building a Lattice for School Leadership: The Top to Bottom Rethinking of Leadership Development in England. Research Report (\#RR-83). Philadelphia: Consortium for Policy Research in Education, University of Pennsylvania.

The views and opinions expressed in this report are soley those of the author and other contributors. These views and opinions do not necessarily represent those of the Consoritum for Policy Research in Education (CPRE), the Thomas B. Fordham Institute, or the Education Foundation.

\begin{abstract}
About the Consortium for Policy Research in Education
The Consortium for Policy Research in Education (CPRE) brings together education experts from renowned research institutions to contribute new knowledge that informs PK-16 education policy and practice. Our work is peer-reviewed and open-access at cpre.org. CPRE's member institutions are the University of Pennsylvania; Teachers College, Columbia University; Harvard University; Stanford University; University of Michigan; University of Wisconsin-Madison; and Northwestern University.
\end{abstract}

\title{
About the Thomas B. Fordham Institute
}

The Thomas B. Fordham Institute is the nation's leader in advancing educational excellence for every child through quality research, analysis, and commentary, as well as on-theground action and advocacy in Ohio.

\section{About the Education Foundation}

The Education Foundation is the UK's first cross sector education think tank, with a mission to accelerate reform and innovation in the British education system and beyond. Cofounded by Ty Goddard and Ian Fordham in 2011, the Education Foundation's work focuses on education reform, technology and innovation and helping to tackle the biggest policy challenges facing the system. This research report forms part of our ongoing program of work entitled "USA UK Ed" that aims to be a catalyst for the exchange of ideas, policy and practice between the two countries. For more details visit www.ednfoundation.org. 


\section{About the Author}

Jonathan Supovitz is an Associate Professor of Education Policy and Leadership at the University of Pennsylvania's Graduate School of Education and Co-Director of the Consortium for Policy Research in Education (CPRE).

Dr. Supovitz is an accomplished mixed-method researcher and evaluator and has published findings from numerous educational studies and evaluations of school and district reform efforts. He has presented his work both nationally and internationally on school leadership development and practice; data use and continuous improvement initiatives; classroom formative assessment practices; and state and district testing and accountability policies. Much of his current research focuses on how school and district leaders create systems for the improvement of teaching and learning. He is a lead and co-investigator of numerous Federal and foundation sponsored research projects. He is also a member of the committee refreshing the Interstate School Leaders Licensure Consortium (ISLLC) Standards. He leads the Evidence-Based Leadership strand of the Mid-Career Educational Leadership Program at the University of Pennsylvania.

Dr. Supovitz is currently leading a large scale evaluation study of a formative assessment initiative in the Philadelphia public schools and co-leading an analysis of the political debate on Twitter around standards implementation in the United States. He recently concluded a four-year study of Common Core implementation in New York City schools that examined the connections between district policy and school and classroom practice. This work offers insight into how the largest school district in the United States interpreted and enacted the Common Core State Standards. 



\section{Acknowledgements}

This paper would not be what it is without invaluable contributions from many people. Bobbi Newman at CPRE was an instrumental partner in this work, helping to bring together background information, discussing themes, scheduling fieldwork, and commenting on drafts.

Ian Fordham and Rashmi Sirdeshpande at the Education Foundation in London helped to situate Bobbi and I about the education context in England and connected us with their network of educators.

Amber Northern and Victoria Sears at the Fordham Institute facilitated some of the early work and Mike Petrilli ably steered the project through some difficult times. Amber, Victoria and Mike all provided helpful feedback on drafts.

Don Peurach at the University of Michigan provided important feedback on the report and helped me sharpen my points and distill the takeaway themes. Andy Hargreaves was kind enough to contribute his incisive foreward.

Jennifer Moore at the Graduate School of Education at the University of Pennsylvania applied her editing acumen to the final draft and Jackie Kerstetter provided her visual touch to the packaging of the report. Anne McEvoy supported me every step of the way. 



\section{Foreword}

Almost half a century ago, educational historian Michael Katz (1971) described four traditions in American education. Two kinds of voluntarism-corporate and paternalistic-referred to private and philanthropic investments that preceded and paralleled the establishment and spread of public education. Democratic localism referred to that great American tradition where democracy is often at its most vigorous-the local community. Finally, Katz detected the historical rise of a fourth strand of American educational history that self-evidently speaks its own nameincipient bureaucracy.

Forty-four years on, U.S. education is still defined by these same traditions, but with some significant shifts. Corporate voluntarism has become corporate privatization; paternalistic voluntarism has become monopolistic philanthropy and incipient bureaucracy has become inescapable national bureaucracy. As Katz himself predicted-except in the small towns, villages and suburbs that make up the majority of America's school districts-the casualty in the ethnically diverse cities of urban America has been democratic localism.

The convergence of inescapable bureaucracy and corporate privatization has also had a second effect-which this paper by leadership and reform expert Jonathan Supovitz addresses and to which it responds. Supovitz articulates an important feature of public education systems-indeed, all large organizations: how they operate vertically in hierarchies of supervision and control and-often quite separately-laterally in the diffusion of practices and ideas. Understated though his style may be, Supovitz is nonetheless very clear that compared to other educational systems, the U.S.'s approach to educational leadership is disturbingly dysfunctional in both vertical and lateral terms.

Vertically, the U.S. school principal hovers over a staff of generally equal status (with each other). There are few or no interceding layers of responsibility, except for the managerial functions of teachers in roles like high school department heads. This system turns instructional leadership into a travesty of what it should be. The end of instructional leadership should be to develop great instruction for all students by working with the school's best experts on instruction to make this happen. Supovitz summarizes how research repeatedly points to how school leaders produce higher achievement by bringing the leaders of instruction across the school together. But because the U.S. has few ways of formally recognizing instructional leadership among the teaching staff, principals are being required not to lead teams of effective teacher leaders, but to be performance managers who are responsible 
for judging good and poor performance. Hovering above the flattened structure of schools, principals are therefore being overwhelmed by their formal observational responsibilities of individual teachers and their lessons. There is just nobody else with the formal authority to do the job.

Laterally, the problems are just as great. Schools are separated from schools. Public schools compete with charter schools, and unless they are in charter management chains, charter schools also compete with each other for students, teachers, and leaders. There are few ways to develop leaders across schools. Turnaround strategies concentrate on individual institutions instead of creating processes so that schools and expert professionals can help each other. Tiny districts compete with neighboring tiny districts. Instead of diffusing practice from one school to another, educators are gathered together to endure drive-by, one-size-fits-all workshops. Leaders feel alone. They do not themselves experience the collaboration among peers that they urge among their teachers.

U.S. education and its leaders are therefore doubly trapped. They are oppressed by vertical bureaucracies and isolated by lateral markets. All this can seem inevitable and inescapable. But Supovitz shows us that systems do not have to be victims of their history. Other systems exist. Other systems also change. U.S. systems can, too. This is the point of Supovitz's very perceptive paper on educational leadership development and coherence in England.

England is an enigma. To American eyes, perhaps, it conjures up images of Downton Abbey, Wimbledon, or the Beatles. But on international indicators of educational performance, England has similar rankings to the U.S.-including degrees of economic and educational inequality.

As the 2014 Scottish referendum reminded us, England cannot be equated with the United Kingdom-which also includes Scotland, Northern Ireland, and Wales. England has its own educational system with greater national curriculum prescription than its three neighbors, more standardized testing (which the other countries have either not introduced or which they abolished when their systems were devolved from England's), and commitment to market incentives and processes that are not matched by the other parts of the U.K.-such as academies and free schools (similar to charter schools in the U.S.), Teach First (the equivalent of Teach for America), and school-based rather than university-based teacher training.

Jonathan Supovitz takes his readers very effectively through a labyrinth of English educational institutions that are culturally and historically unique and not always easy to grasp from a U.S. standpoint. He also sets out to interpret and contextualize 
them. As an Englishman who has worked and lived in the US for more than a decade and still finds parts of the U.S. system of licensure and administration baffling, I have great admiration for the cross-cultural interpretation that Supovitz has achieved in the other direction. From the standpoint of my English background, and as someone who was appointed for ten years as a Special Professor to the National College of School Leadership and as an Associate Director of the Specialist Schools and Academies Trust-the two most influential leadership organizations in education in the country-here are a few key pieces of the backstory, most of which Supovitz picks up himself.

Until the early 1980s, England was in what I have described elsewhere as a First Way of educational change-a way of innovation and inconsistency (Hargreaves \& Shirley, 2009). The system was highly decentralized by a local education authority or school district. There was no national curriculum or testing system except secondary school examinations at ages 16 and 18. Headteachers were all-powerful in their schools, sometimes innovative, often not. Schools and teachers constructed their own curriculum-often with leanings to child-centredness in primary schools and more traditional orientations in secondary schools. A system of Her Majesty's Inspectors inspected schools periodically, issued confidential reports, provided feedback, and never pronounced schools to be failures.

Following a period of attempts to create some kind of national direction in the first half of the 80s, the Thatcher government then plunged the country into the full force of a Second Way of educational change defined by markets and particularly standardization. A National Curriculum was introduced in 1988, becoming one of the most detailed national prescriptions of content in the world. Standardized testing followed in three subjects at three age points, and the results were made public. Parental choice of schools was fuelled by publication of test score rankings. The inspection system was revamped to include categories of failure or near-failure and dramatic interventions typically followed. Test scores played a significant part in the inspection reports that were made public. Research showed widespread teaching to the test, narrowing of the curriculum, and gaming of the system. School leaders (headteachers) turned into performance managers whose job was to implement the dictates of the system.

Thatcher was followed by Blair who was advised by Sir Michael Barber. Much of the Thatcher framework persisted, though with the addition of significantly more resources. The National Curriculum remained for several years, as did standardized testing, along with an inspection system that was widely regarded by the profession as being excessively punitive. In addition, a highly prescriptive National Literacy and Numeracy Strategy was introduced that was closely tied to the testing process. 
But as well as providing increased resources for improvement, the Blair government also introduced a number of important innovations. Two of these are discussed in depth by Supovitz in this paper.

First was the inspired creation of a National College for School Leadership that created a leadership framework and qualification system not just for head teachers, but also for all kinds of other leaders, such as aspiring leaders and middle-level leaders in schools. Inspired by an annual national conference, informed by a series of commissioned research studies and position papers, and driven by the knowledge and expertise of experienced school leaders themselves, the College, in this small but densely populated nation, gave school leadership of all kinds of status, professional recognition, and a foundation of knowledge and continuous learning. Supovitz describes the College's work and impact in considerable detail, showing that although the U.S. may not be able or even want to clone England's model, it can certainly consider adopting some of the College's design principles as well as a number of its specific activities.

A second initiative was the counterintuitive development within a highly competitive system of cross-school collaboration and peer-to-peer learning. In Uplifting Leadership, Alan Boyle, Alma Harris and I describe how co-opetition (the combination of collaboration and competition) is increasingly common in business and in sport (Hargreaves, Boyle, \& Harris, 2014). We also documented how this process worked in the London boroughs of Tower Hamlets and Hackney, where schools that were direct competitors helped to lift each other out of failure into success and where they shared responsibilities for placement of disruptive students. These associations between schools became known as federations, and in the most successful ones, high-performing head teachers would, by mutual consent, take on responsibility (and increased resources and salary) for a second and sometimes a third, fourth, and fifth school as they progressively came out of failing status. In this way, systems of school-to-school coherence and cohesion were built from the bottom up, not imposed from the top down.

The development and growth of these initiatives under a more explicitly marketdriven Conservative government is uncertain and contested. But what is clear, in Supovitz's terms, is that England has evolved a pattern of vertical and lateral leadership development that carries many important lessons for other countries. The cultures and contexts of other countries like the U.S. may require different specific solutions, but the questions are important. Should there be a national framework for leadership development that is more than an agreed set of standards? How can schools work with schools and turn around other struggling schools, even and especially when they are competitors? How can educators in the 
US extricate themselves from bureaucratic oppression and lateral isolation? How can the US system spread leadership knowledge and support more effectively? What does this mean for assumptions about accountability?

The best closing words are Supovitz's own especially wise ones; "The American system would benefit from a formal expansion of leadership positions in schools from the traditional reliance on a strong single actor with a weak supporting cast, towards a more deliberately integrated system of school leadership".

\section{Andy Hargreaves}

Brennan Chair, Lynch School of Education, Boston College

Education Advisor to the Premier and Minister of Education of Ontario 



\section{Executive Summary}

Where do new policy ideas come from? Sometimes they come from inside a system, when someone comes up with a better way of doing things. Sometimes they come from cross-industry learning, when someone looks to another field and sees things constructed in a way that can be transplanted from one sector to another. And sometimes people gain new insights from looking at how different contexts have responded to similar challenges. In this report I take the latter approach, examining the educational leadership development system in England to see what, if any, ideas American leaders and policy makers might learn from looking cross-nationally. There are several important differences between the way that educational leadership is designed, supported, and carried out in English schools in comparison with schools in the United States. It is worthwhile for us to consider the value of these English approaches for the American context.

Over the past 15 years, England has introduced substantial reforms to the ways educational leadership is designed and carried out in schools. First, it has developed a set of formal educational leadership positions in schools that go beyond the principal and one or two others. The clarity of the roles and responsibilities of three levels of school leadership-school principals, senior leaders, and middle leadersare a striking contrast to the informal ways that teacher leadership is fostered in the United States. Particularly innovative from the U.S. perspective is the set of middle leaders who are formally responsible for teaching, learning, and behavior in subject areas or grade groups. The overall school leadership structure in England adds depth to the professional support that teachers get and moves responsibility for instructional improvement closer to the classroom. The tripartite structure has also created pathways for teachers to become school leaders, and for leaders to develop and refine their skills across their professional careers.

To support school leaders, England's government charged a quasi-governmental organization, the National College of School Leadership, to define the knowledge and skills necessary to lead at each of the three levels and to develop a high quality curriculum to build the capacity of leaders to competently perform at each level. The National College curriculum brought together a rich set of blended learning experiences that culminate in an assessment for a nationally accredited certification for each leadership level. Tens of thousands of school leaders have received the national certification.

More recently, the government has shifted to a more decentralized emphasis by facilitating school networks to enable lateral school exchanges, led by high performing schools. Because these networks are closer to particular problems of practice, they are more grounded and responsive to the specific challenges 
and needs of participating schools. I call this combination of vertical leadership development and lateral school network support the lattice for school leadership.

Finally, and crucially, school leadership and effective teaching are central elements of the national school inspection process, which is the cornerstone of the nation's school accountability system. By incorporating school leadership and instructional practice into school performance judgments, the essential role of these elements is reinforced and the signals for what schools should focus on are broadened beyond test performance.

Thus, the lattice for school leadership in England is the careful integration of formal and social learning opportunities for leaders. It features a centrally developed, high quality leadership development program combined with lateral social networks. These complementary elements of leadership development are carefully enmeshed in a system that provides clear responsibilities for multiple levels of leadership within schools, incentives for identifying and grooming leadership within schools, pathways for leadership progression, and certification for leader attainments. All of these elements are supported by an accountability structure that emphasizes the contribution of school leadership and teaching to school improvement.

The concept of a lattice for school leadership challenges educational leaders and policy makers to hold multiple, sometimes competing, conceptions in their heads. Such a system combines centralized and decentralized structures, formal and social learning approaches, and multiple system actors.

Finally, it is worth noting that identifying sensible ideas is different from successfully incorporating them into a different culture and a different education system. Though there are important concepts within this report that should enter the policy debate, I do not underestimate the hard thinking, planning, and resource allocation that would need to occur for any of these ideas to be fruitfully incorporated into American education. I argue they are worthwhile to consider in order to bolster the educational leadership system that is so integral to high educational performance. 


\section{Prologue}

Kelly Robertson picked a tumultuous time to jump from the frying pan into the fire. A 12-year teaching veteran at a secondary school in a low-income area about 30 miles outside of London, Kelly was chosen about a year ago by her school's head teacher to enroll in Teaching Leaders, a two-year training program for middle leaders in challenging schools. "It's a big commitment, because it meant giving up a week of my summer holiday and Saturdays without pay," Kelly said. Teaching Leaders is a government-subsidized program that provides training, coaching, and a network of support for mid-level school leaders. The program culminates in a performance examination for the National Professional Qualification for Middle Leaders (NPQML), a distinctive certification in England for teachers who lead a department, grade level, or other group within a school.

Just as Kelly was undergoing her middle leader development, the school was inspected by the Office of Standards in Education - the accountability mechanism for the nation's schools - and received the lowest school quality rating, indicating that the school was failing to provide an acceptable level of education for its students and that it lacked the current leadership capacity to make improvements. The school's governing board forced the head teacher (principal) to resign, and the school is now being run by the executive head of a regional teaching school that leads a school development network. The school's poor rating and leadership transition resulted in steep staff turnover, a restructuring of the school's organizing systems and faculty responsibilities, a renewed commitment to staff development, and, as Kelly put it, "a massive overhaul of teaching and learning."

Now Kelly's leadership training is needed more than ever. Beyond the summer leadership session, Kelly attends training sessions on selective Saturdays on topics such as managing up, strategic thinking, and managing effective teams. She also meets a couple of times a year with other middle leaders in her cohort for what she calls "offloading sessions." "The cohort model is so important," she said. "I was naïve to think my school was good, and the relationships I have built with the network of colleagues have really broadened my sense of what is possible." Another important part of her experience is her leadership coach, a well-respected former school leader and inspector, who meets with Kelly at her school every other month and with whom she has regular phone conversations. "One of the biggest things I have learned from my coach is how to manage people," Kelly said. "If anything, I have learned to take a step back. In any workplace you form friendships as well as working relationships, and I had to think about my approach to people to monitor the work they are doing," she said. "It's been difficult at times." 
While preparing for the NPQML, Kelly is the head of a team that is responsible for 300 of the school's 1,200 students. She manages the teachers on her team, working with different subject departments to put interventions in place, identify students who are underachieving, work with families to support their children, and mentor and coach teachers. Her main responsibility is helping teachers improve their instruction to achieve learning outcomes for students. She has received extensive training on the important qualities of instruction, and she works with teachers to engage their pupils in their lessons, keep their grading up to date, set learning targets, accurately level their lessons, and put in place particular interventions and differentiation for vulnerable students with special needs or who qualify for free school meals. What she finds most difficult is "having challenging conversations without estranging the relationship you want to have with people, which is the basis of your ability to have influence and guide them." Kelly's experience, like that of so many teachers in England who now hold formal middle leader positions in schools, is being shaped by the changing policy context of leadership development and school organization in England. 


\section{Introduction}

England is a small nation with a burgeoning public education system. Although geographically the size of Wisconsin, the country publicly funds about 20,000 schools - the equivalent of the number of public schools in California and Texas combined. This includes about 16,800 primary schools and 3,300 secondary schools. The government also funds a number of public faith-based schools, mostly affiliated with the Church of England and the Roman Catholic Church. In terms of performance, England typically ranks in the top third of performance on international comparisons and generally outperforms the United States. For example, on the 2012 Program for International Student Assessment (PISA) exam taken by students in 65 nations, England ranked ahead of the United States in mathematics, reading, and science.

Traditionally, the English education system has been strongly centralized, with a national curriculum and a national accountability system. But increasingly, the government has sought to decentralize, turning to more localized and market-based mechanisms to spur continued innovation and improvement.

Over the past 20 years, England, as well as many other European nations, has dramatically rethought how school leaders are professionally developed. These efforts were highlighted in a 2012 Organization for Economic Cooperation and Development (OECD) report that distilled lessons from around the world about how nations prepare school leaders (Schleicher, 2012). The report first identified a set of research-informed leadership competencies that define effective school leadership. These included setting school goals in coordination with external expectations; creating, aligning, and continually adjusting curricula and programs to meet these goals; strategically managing available resources, with a particular emphasis on supporting, developing, and evaluating teachers as a primary school resource; and developing and facilitating collaborative work environments.

The OECD report authors then examined the different approaches that the 34 OECD member countries employed to develop their school leaders. They featured a few particularly promising leadership development systems, spotlighting Australia, Canada, England, Finland, and Singapore, which the authors judged had done exemplary work in leadership development. England was one of only eight countries cited as having strong pre-service, induction, and in-service systems. Furthermore, the report noted evidence of greater improvements in English schools whose leaders had participated in the national leadership development program compared with those who had not.

The purpose of this report is to examine what American policy makers can learn from the English system. How is leadership development organized in 
England? How does leadership fit into the larger system of efforts for educational improvement? Though there are big differences in both education tradition and geography between the United States and England, there are also important similarities. Both countries are focused on improving subject matter teaching and academic learning as a central mission of their educational systems. Both countries put a high premium on school leadership and leadership development as a means for school improvement. Further, both nations have framed their systems to emphasize capacity building and accountability as key pillars of the government's role.

This report tells the story of an ongoing effort by leaders of England's education system to develop the two strands of what I call a lattice for school leadership. These strands integrate a centrally designed system of training and development for school leaders at different levels within a school with a network of ongoing, school-embedded leadership development opportunities led by high performing schools that is grounded in the exigencies of local need and practice. Both the career development hierarchy and more horizontal cross-school networks are nested within an education system that recognizes leadership attainment and makes leadership a visible and central part of the national school accountability system.

Although this system is imperfect and its development continues to unfold, important lessons can already be distilled for education leaders in the United States. These include:

- the formalization of multiple leadership positions within schools, going beyond the principal to include senior leaders and middle-level leaders. These positions deepen support for the improvement of teaching and learning while also creating chances to identify potential leaders, career pathways for promising and interested teachers to become leaders, and opportunities for current leaders to continually refine their professional skills;

- the identification of a set of leadership competencies at each of the leadership levels;

- the development of a robust system of learning opportunities to build the capacity of leadership at each level;

- the creation of a nationally recognized qualification for school leadership;

- the stimulation of rich networks of schools and leaders to collaborate on both leadership development and grounded problems of practice;

- the creation of high profile incentives as well as appropriately targeted pressure to encourage ongoing leadership development and promote its role in the urgency for school improvement. 


\section{Growing Recognition of Leadership as a Driver of School Improvement}

School leadership is increasingly seen as an essential component of school improvement. In perhaps the most comprehensive contemporary review of the impacts of school leadership, Leithwood, Seashore Louis, Anderson, and Wahlstrom (2004) conducted an exhaustive review of over 300 studies of school leadership and concluded that among school-related factors that contribute to what students learn at school, leadership was second only to classroom instruction. Moreover, they found that the effects of leadership were magnified in more challenging educational contexts.

Another important finding of the Leithwood et al. (2004) report was the largely indirect nature of school leadership. That is, effective principals work in a variety of both direct and ancillary ways to influence the practice of teachers-like facilitating experiences for teachers or creating opportunities for teachers to interact with one another around issues of teaching and learning-and that these indirect routes of influence are hugely important. This finding is supported by a number of investigations of the relationship between principal practice and student outcomes. Hallinger and Heck (1998), for example, synthesized 43 empirical studies conducted between 1980 and 1995 that investigated evidence of the relationship between principal leadership and student achievement. They saw little evidence of direct effects, with most evidence pointing to indirect effects. They concluded that principals have a measurable, but indirect, effect on school effectiveness and student achievement. In a more recent study of leadership in one American school district, my colleagues and I estimated both the direct and indirect effects of leadership on instructional practice and student learning. We found that the magnitude of the indirect effects of principals' creating opportunities for teachers to interact was almost twice the size of direct influence that principals have on teachers' instructional practice (Supovitz, Sirinides, \& May, 2010).

American research on school leadership has fixated on two areas. First, we are enamored with the style that individual leaders use to influence practice within their organizations. A number of studies, for example, have analyzed the impacts on teacher perceptions and behaviors, as well as student outcomes, associated with transactional and transformational leadership approaches (Hallinger, 2003; Leithwood \& Jantzi, 2000; Silins, 1994). Second, we have a very singular notion of school leadership as the sole domain of one individual, the principal. Going back to Wolcott's (1974) archetypal book depicting the principal as the unitary leader of 
a school, America has tended to view leadership beyond the principal's office as organic rather than a conscious development and positioning of talent. Most efforts to study school leadership also tend to assume an informal leadership structure in schools. For example, a large body of research on teacher leadership points out the ill-defined role of teacher leaders and their struggles to influence the practice of their peers due to their unclear status (Mangin \& Stoelinga, 2009; Supovitz, 2008; York-Barr \& Duke, 2004). Beneath the principal, the structure of schools is exceedingly flat.

Another example of the largely informal construction of leadership in U.S. schools is that of interventions around distributed leadership. Spillane (2006) originally conceptualized distributed leadership as a perspective for looking at who plays leadership and followership roles around tasks in schools. But in the distributed leadership models that I have examined, teachers are given elevated leader status in their schools without formal authority to influence the instructional practice of their peers (Supovitz \& Riggan, 2012; Supovitz \& Tognatta, 2013).

Similarly, while assistant principals and secondary school department chairs are fixtures in American school structures, we pay scant attention to how they fit into the larger picture of school improvement.

An important source of guidance for school leadership in the United States comes from a set of standards called the Interstate School Leaders Licensure Consortium (ISLLC) Standards. The ISLLC standards were developed in 1997 by the Council of Chief State School Officers in collaboration with the National Policy Board on Educational Administration to help strengthen preparation programs in school leadership (Van Meter \& Murphy, 1997); they are currently being revised. The ISLLC standards consist of six overarching leadership standards: (1) Vision, (2) School Culture and Instructional Programs, (3) Management, (4) Community and Families, (5) Ethical Behavior, and (6) Context, each with a detailed set of knowledge, dispositions, and performances. They are intended to guide the actions of leaders and, more importantly, provide a framework for leadership development. Most states and districts use the ISLLC standards for organizing leadership development.

To hold a principalship, principals in each of the 50 states in the United States are required to have a master's degree, to have some number of years of relevant experience (usually, but not necessarily, in an educational setting), and to pass a state certification exam. For example, Pennsylvania requires candidates to complete an approved program of graduate study in school administration, to have three years of relevant experience in an educational setting, and to pass a certification exam. In Illinois, candidates must hold at least a master's degree with coursework in educational administration and supervision, complete a state-approved program for the preparation of school administrators, and pass a multiple-choice examination. 
In California, candidates must already hold a teaching credential, complete a stateapproved preparation program, and pass a state exam that includes multiple-choice questions, open-ended response items, and a case study response.

\section{Beyond initial}

certification, the ongoing development of school leaders in the United States has been largely left to school districts and self-motivated, inquisitive individual leaders. Most large school districts have school leadership development programs that provide training and support for principals. In addition, there are a few high profile national models of school leadership development. These include the National Institute for School Leadership, New Leaders, and the New York City Leadership Academy (see box). The Wallace Foundation is also funding leadership pipeline projects in six large and mid-sized districts (Turnbull, Riley, Arcaira, Anderson, \& MacFarlane, 2013). Thus, the policies of school leadership development vary greatly from state to state and even from district to district.
Prominent American Leadership Development Programs

\section{National Institute for School Leadership}

The National Institute for School Leadership (NISL) provides training for aspiring, novice, and veteran school leaders. Presently NISL works with 21 states and approximately 50 districts to train aspiring leaders, current principals, and school leadership teams. NISL emphasizes leadership knowledge and skills, teaching and learning, and subjectarea content knowledge. The program delivers leadership training through 13 two-day units. Typically cohorts of 15-45 participants are trained by NISL trainers using simulations, job-embedded learning, case studies, and 360-degree leadership assessment tools.

\section{New Leaders}

Founded in 2000, New Leaders is a national non-profit leadership development organization that has trained nearly 800 school leaders in urban districts across eight states. New Leaders provides three levels of leadership development: Emerging Leaders, Aspiring Principals Program, and Principals Institute. Training is focused on four leadership domains: Personal Leadership, Adult \& Team Leadership, Cultural Leadership, and Instructional Leadership. Recently, New Leaders partnered with Teach for America to develop the leadership skills of Managers of Teacher Leader Development (MTLD) in New Leaders partner sites.

\section{The New York City (NYC) Leadership Academy}

The NYC Leadership Academy was modeled after the management training program of General Electric under Jack Welch. For over 10 years the NYC Leadership Academy has been training aspiring principals in three phases. First, participants are immersed in a 6-week summer institute. Second, they participate in a 6-month school-based residency with an experienced principal as a mentor. Third, participants transition into a leadership position in the NYC schools. All participants must commit to serving in NYC for 5 years. For sitting principals, the NYC Leadership Academy provides jobembedded support through specialized coaching. Currently, about one in six of New York City's 1,600 school principals is an NYC Leadership Academy graduate. In addition to its work in the nation's largest district, the NYC Leadership Academy also assists school districts and state education agencies in 25 states across the US to develop their school leadership programs. 


\section{An Initial Framework for Examining a Leadership Development System}

What are the key elements of a robust leadership development system, and how should they be sequenced? To organize my investigation of the components of the leadership development system in England, I initially adopted a framework of talent management. This framework is commonly used in the business world to guide the human resource processes that are designed to attract, develop, motivate, and retain productive employees (Berger \& Berger, 2011; Cappelli, 2008). The educational leadership talent management pipeline that I used to guide my investigation and interview protocols is depicted as the five-stage process represented in Figure 1: (1) identifying and recruiting potential leaders; (2) developing potential leaders before they take on specific leadership responsibilities (pre-service); (3) licensing leaders as a mechanism of quality assurance; (4) providing ongoing professional development (PD) of leaders; and (5) planning for the succession of leaders.

Figure 1. Framework for a Leadership Development Pipeline

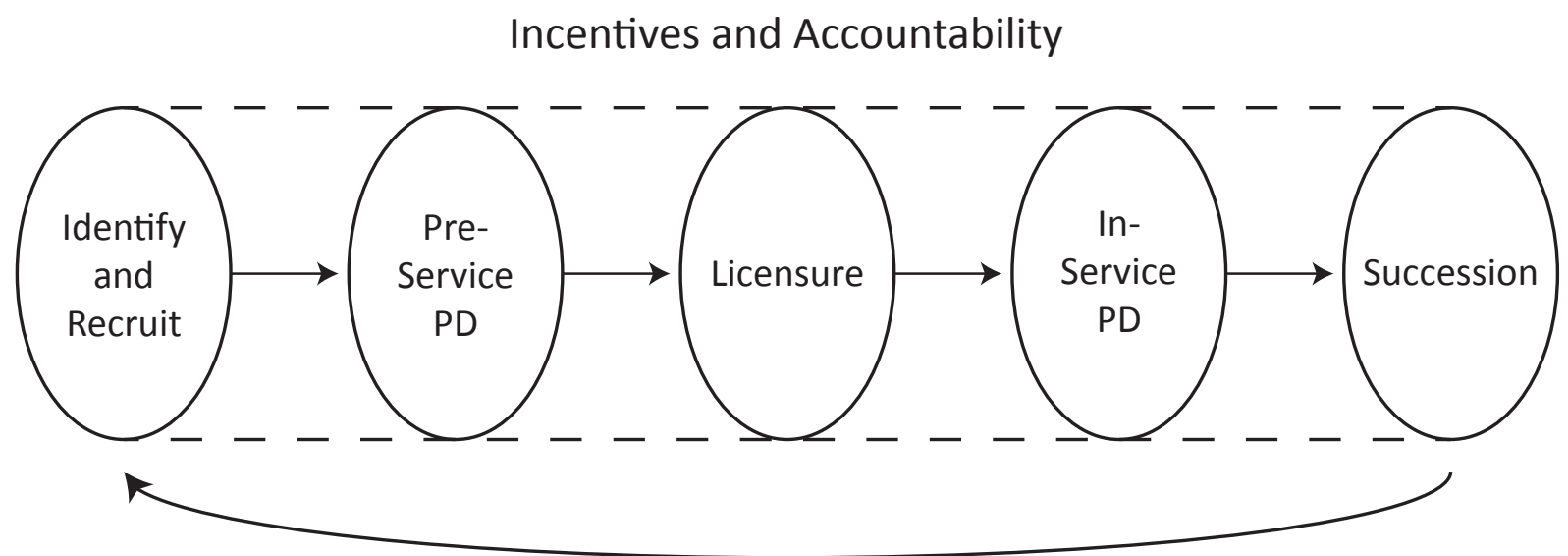

In addition, giving leaders incentives and holding them accountable for their performance are key aspects of a holistic leadership development system, but rewards and pressure are likely to come from aspects of a broader system outside of the infrastructure of leadership development; therefore, I have placed them outside of the pipeline in Figure 1. Finally, since succession planning often involves a replication of the process, the arrow at the bottom of the figure depicts the iterative nature of leadership development within organizations. This framework, although useful, proved too rudimentary to capture the complex set of interdependent initiatives designed to deepen school leadership practice in England, as I demonstrate in the following sections. 


\section{The Evolution of Leadership Development in England}

England's efforts to develop school leaders over the past 15 years have occurred in two distinct phases that largely align with the eras of the Blair and Cameron governments. The first phase was a concerted effort to develop a centralized strategy to specify leadership pathways in schools and develop a system to build the capacity of leaders to follow these pathways. The second, more recent, reforms have taken a more decentralized approach to using school-led local networks to laterally build leadership capacity. I explain both approaches in detail in the following sections.

\section{A Centralized Vision for Developing Leadership Expertise in Schools}

For the past 15 years, the cerebral cortex of the English leadership development system has been headquartered within the National College of Teaching and Leadership on Triumph Road in Nottingham, where some of the best thinking on leadership development has occurred. In 2002, with great fanfare, Prime Minister Tony Blair christened a new $£ 28$ million leadership training center on the site. Initially funded as a non-departmental public body-which gave it some autonomy from the strictures of ministerial direction and control-the National College has led the intellectual movement to articulate what English school leaders should know and be able to do, and to equip them with the knowledge and skills to do so. The rationale for the National College, according to Charlie Taylor, its current chief executive, was the increasing demands placed on school leaders. "As schools got more autonomy, head teachers got more responsibility for a wider range of things, so the challenge was that the role of heads (principals) began to change, and the risk was that heads would become managers instead of leaders, and they would lose track of the really important leadership things they needed to do," explained Taylor. "And given that we know that leadership is the most important thing in terms of improving schools, what is it that the government can do to improve the quality of leadership and therefore improve the quality of schools?" he added. To induce schools to invest in their leadership learning, the National College developed a comprehensive professional development curriculum and delivery structure.

The core leadership development strategy of the National College was the creation and direct delivery of a sequence of training modules that led to an assessment and qualification for three types of school leaders: head teachers, senior leaders, and middle leaders. Head teachers are the equivalent of principals in the American 
system. Senior leaders are similar to assistant or vice principals in the U.S., but with clearer school-wide responsibilities. Middle leaders are positionally akin to secondary school department chairs or grade-level or grade-range (i.e., $\mathrm{K}-2,3-5$ ) leaders in America.

Figure 2. Training Sequence Leading to National Professional Qualifications

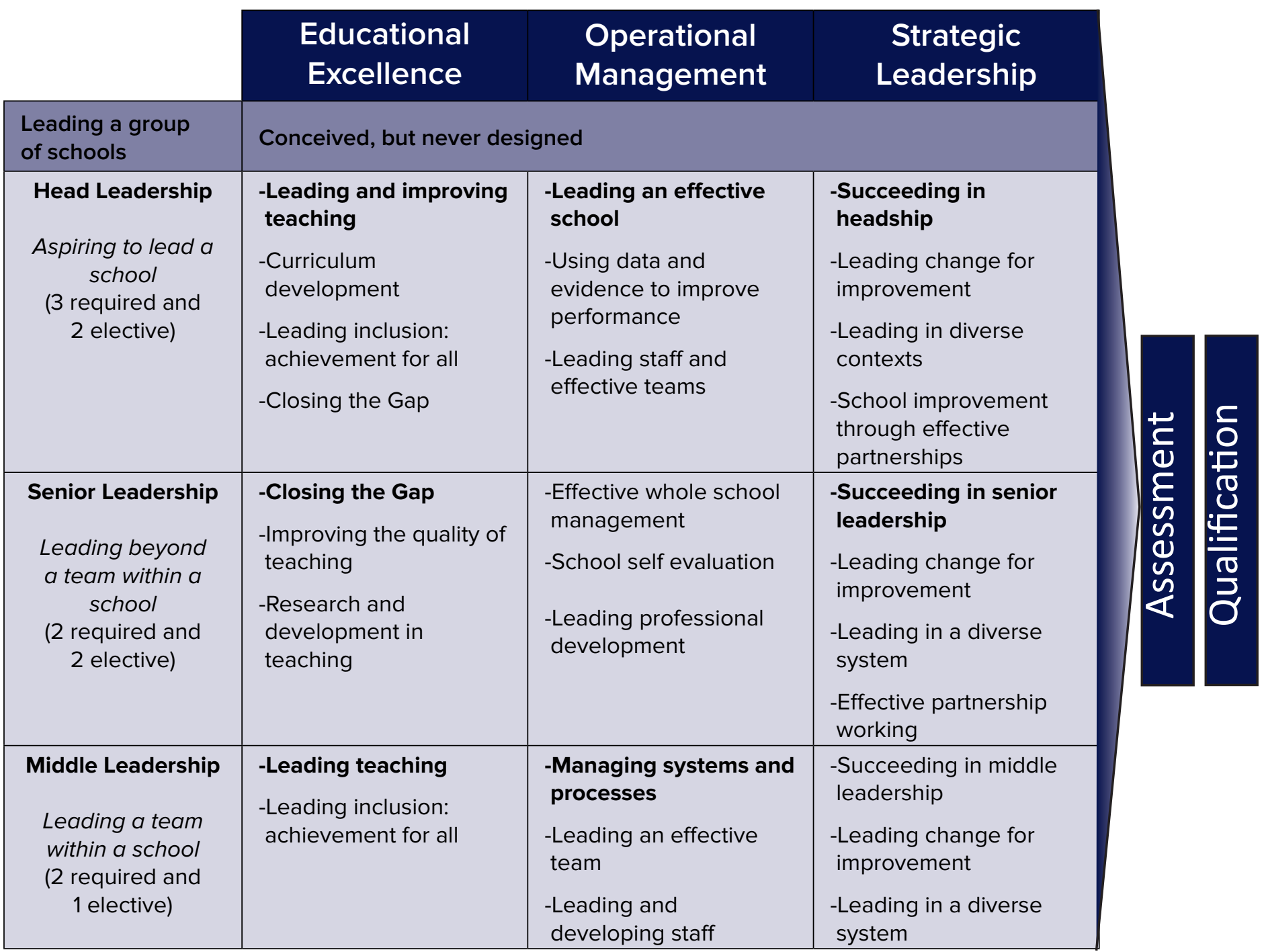

Required modules are in bold.

The legitimation of each of these three types of leadership positions-particularly middle leaders-in schools, the identification of clear responsibilities for each role, and a progression among them has created an infrastructure for school improvement and accountability that is quite distinctive. "Middle leadership is the engine room of the school that drives performance, but it just doesn't get the attention that head leadership does," according to James Toop, the chief executive of Teaching Leaders, the non-profit organization that helps to identify and professionally develop middle leaders in disadvantaged areas across England. 
The training sequence designed by the National College for each of the three leadership levels - head teachers, senior leaders, and middle leaders-is shown in Figure 2. Professional development for each level is organized into three major categories: educational excellence, operational management, and strategic leadership. These categories capture the three essential challenges of school leadership identified by the National College: (a) improving the core school function of instruction; (b) managing the operations of the organization; and (c) developing the skills to motivate, influence, and hold others accountable for their professional performance. For each level there are a series of required and elective modules distributed across these three major categories that signal what the National College views as the priority skills at each leadership level. Additional levels, like leading a group of schools, were envisioned but never developed.

The curriculum developed by the National College for leaders at the different levels is very detailed. As summarized in Figure 2, leaders must take three to five modules (depending on the qualification level) and pass an examination. Each module requires up to 50 hours of learning. The training is a blended learning experience 46 The strength of the curriculum
is that it is an opportunity to
get staff out of their schools
and to help them start thinking
beyond their pedagogy in the
classroom, to develop their skills
to influence others. $\mathbf{7}$ of face-to-face sessions and online mixed-media assignments (readings, videos, threaded conversations). The curriculum also includes projects that are designed to connect out-of-school learning and in-school work. Additionally, the programs have evolved to be designed for cohorts, rather than individuals, which creates a strong peer-learning and peer-support experience. To further bolster the experience, participants are assigned both an external coach and a school mentor.

The general consensus among key stakeholders interviewed was that the quality of the curriculum was excellent, but that it could also be overwhelming for practitioners. Jenny Francis, the program leader at the Institute of Education at the University of London, said that "the content and range of materials is brilliant. There are think pieces, examples of good practice, links to videos of people talking about what they have done in their schools and its impact. There are bits of theory and pieces from textbooks. Its breadth is extraordinary." Even so, she noted that to expect a school deputy head to do all the reading was both cumbersome and unrealistic. According to Francis, "the strength of the curriculum is that it is an opportunity to get staff out of their schools and to help them start thinking beyond their pedagogy in the classroom, to develop their skills to influence others. This is a real battle in this country to get people to think about the relationship between 
leadership and outcomes. For them to get that level of understanding that if you are a good leader with strong skills-if you motivate people and encourage them and hold them to account - that the children are going to improve," she said. "But it's quite a hard battle."

Another challenge underlying the curriculum was how to make classroom- and onlinelearning experiences have an enduring influence on the dayto-day work of school leaders. Toby Greany, formerly the Director of Research and Policy at the National College for seven years and one of the main architects of the leadership curriculum, raised this issue in our interview. "Many of the early leadership programs offered by the National College were seen as offering high quality content, but with insufficient application in practice," he said. "Too often the programs were seen as teaching people the language of leadership, but not the practice. If you go on a course but don't have opportunities to apply the learning in practice, then it dissipates quickly." The National College tried to counteract this, Greany told me, by requiring participants to undertake school-based assignments to learn about leadership and support school improvement at the same time. "With the modular structure and licensed delivery model, the College tried to learn these lessons by embedding leadership development in
Table 1. Chronology of Nationally Supported Leadership Development in England

\begin{tabular}{l|l}
\hline Date & Event \\
\hline $\mathbf{2 0 0 0}$ & $\begin{array}{l}\text { National College for School Leadership (NCSL) } \\
\text { founded as a non-departmental public body-with } \\
\text { distance from government. Early years spent on } \\
\text { leadership development framework-describing } \\
\text { what leaders at different levels need. }\end{array}$ \\
\hline $\mathbf{2 0 0 2}$ & $\begin{array}{l}\text { NCSL develops and begins delivering training for } \\
\text { head teachers. }\end{array}$ \\
\hline $\mathbf{2 0 0 4}$ & $\begin{array}{l}\text { National Professional Qualification for Headship } \\
\text { (NPQH) is initiated. }\end{array}$ \\
\hline $\mathbf{2 0 0 8}$ & $\begin{array}{l}\text { NPQH becomes mandatory for head teachers; } \\
\text { NCSL develops and begins delivering training for } \\
\text { middle leaders and senior leaders. }\end{array}$ \\
\hline $\mathbf{2 0 0 9}$ & $\begin{array}{l}\text { Leadership development increasingly delivered } \\
\text { through a cluster model whereby schools formed } \\
\text { clusters to participate in middle leadership } \\
\text { development. }\end{array}$ \\
\hline $\mathbf{2 0 1 0}$ & NPQH becomes voluntary. \\
\hline $\mathbf{2 0 1 1}$ & $\begin{array}{l}\text { NCSL merges teaching and school leadership } \\
\text { and becomes National College for Teaching and } \\
\text { Leadership (NCTL). }\end{array}$ \\
\hline $\mathbf{2 0 1 2}$ & $\begin{array}{l}\text { National Professional Qualification for Middle } \\
\text { Leaders (NPQML) and National Professional } \\
\text { Qualification for Senior Leaders (NPQSL) begin. }\end{array}$ \\
\hline $\begin{array}{l}\text { NCTL stops direct delivery, selects 33 licensees to } \\
\text { deliver leadership development across country. }\end{array}$ \\
$\begin{array}{l}\text { NCTL becomes an Executive Agency of the } \\
\text { Department for Education. }\end{array}$ \\
$\begin{array}{l}\text { Licenses with leadership curriculum delivery } \\
\text { providers will expire. }\end{array}$ \\
\hline $\mathbf{2 0}$
\end{tabular}


the day-to-day work of schools, with a national structure to give it credibility and quality assurance," Greany explained.

Thus, in addition to completing the coursework, participants must conduct at least one project, either in their own school or another school, that connects their coursework to their leadership work. Writing up these projects becomes their submission for the national qualification that demonstrates that candidates have put what they learned in the modules into practice. The successful completion of the training results in a National Professional Qualification, which certifies that the candidate has successfully acquired the knowledge and skills that the National College believes is necessary to lead at the relevant school level.

The national qualification at each level accomplishes four things. First, it provides a seal of readiness for successful candidates that verifies that they have completed a nationally certified training program in preparation for that level of leadership. Second, by making the system national, the National College ensures that leadership skill development is fairly consistent across the different regions of the country, signaling that someone who has completed the program in the north of England has focused on the same skills and qualifications as someone in the south of the country. Third, and importantly, the sequence of qualifications (from middle leader to senior leader to head teacher) creates a professional career progression for school leaders. Fourth, this progression creates a pipeline for channeling potentially qualified candidates into school leadership positions. As Aidan Melling, the deputy director of leadership at the National College, explained to me in a Skype interview, "We are focused on assuring there is a pipeline of leadership through the system from middle leadership to senior leadership to the headship. We've been quite active over the last 5 to 10 years in supporting schools to develop talent-spotting strategies and helping to incentivize talent spotting, particularly in areas of need like faith schools and small schools in rural areas."

Another important component of the National College's effort to ground the leadership development system in practice is the requirement that at least 50 percent of the delivery of training be delivered by current school leaders. There is a "knock on benefit" to this, pointed out Melling, because these principals not only deliver training, but have to re-engage with the material to teach it. Some retired school leaders are also recruited to deliver the modules, tapping their experience and prolonging their careers.

The National College curriculum typically takes 2 years to complete, and the cost is roughly equivalent to that of many external teacher leadership training programs in the United States. Head leadership training costs about $£ 2,500$ (about US $\$ 4,000$ ) per participant per year, with partial or full scholarships available to smaller schools and schools in higher poverty areas. The senior leadership $(£ 1,400)$ and middle leadership $(€ 1,050)$ curricula are less expensive but offer similar scholarship 
arrangements. Even so, convincing schools to $\mathbf{4}$ Like all small- and medium-sized invest in their professional capacity is a tough sell when there are so many other urgent priorities competing for their attention. "Like all small- and medium-sized enterprises, schools don't invest in professional development anywhere as much as they should, even though people are their basic asset and they spend $90 \%$ of their budget on staffing. 17 enterprises, schools don't invest in professional development anywhere as much as they should, even though people are their basic asset and they spend 90 percent of their budget on staffing," said Greany, the former Director of Research and Policy at the National College.

The articulation of the leadership progression in England has been refined over the past 15 years. Initially, according to Melling of the National College, the leadership curriculum for each level focused on a set of stand-alone courses and yearlong non-modular programs for school leaders. Over time, using "customer research" that showed that school leaders wanted more flexibility, the courses evolved into a more coherent sequence of professional development modules and experiences that linked to master's-level content and led to the national qualification. "The evidence internationally is that there may be many approaches to leadership development, but that most successful systems have a clear approach," said Melling.

Early on, the National College worried that educators would take the subsidized courses for the credential without ever moving into leadership positions in their schools. Therefore, to minimize educators' taking the courses merely for personal interest, there is a pre-enrollment screening process. For the National Professional Qualification for Headship (NPQH), there is a nationally run process in which candidates must submit a written application to demonstrate their leadership and participate in an in-person interview. For the National Professional Qualification for Middle Leadership (NPQML) and the National Professional Qualification for Senior Leadership (NPQSL), which were introduced in 2012, the provider of the training is required to assess the suitability of participants joining the program. After candidates pass the screening process, they must complete a set of required and elective modules and then pass an end-of-program assessment. These barriers are intended to weed out the faint of heart, but also likely deter some potentially talented candidates.

Like the national curriculum, the delivery model has also evolved. From 2000 through 2005, the National College both developed and directly delivered, through a commissioning process, the training for school leaders across the country. Trainers were either full-time National College employees or retired school leaders who 
contracted with the National College to do this work. Initially, the training was offered to individuals, but the National College began to recognize the power of cohorts to enable peer learning and support.

As the National College refined the quality of the curriculum and made the experience for participants more robust, its centrally delivered model became increasingly out of step with the government's decentralization efforts. In response, both the leadership delivery model and the certification model were modified.

In 2010, the Cameron government decided that the National Professional Qualifications for Headship should be optional. This represented a paradigmatic shift in thinking-from seeing the qualification as a basic requirement for holding a school leadership position to viewing it as a mark of quality that aspiring leaders seek out. "Our aim in 2010 was to make the NPQH the qualification of choice," said Melling of the National College. "So what we did was to redesign it with a higher entry bar and an application process and make it more rigorous, so it would be the preferred qualification with a higher quality candidate," he explained. According to Taylor, the National College's chief executive, survey results suggest that $80 \%$ of educators think the qualification is desirable or necessary. The effect that this shift will have is unclear, and the school practitioners I talked to still viewed the qualification as an important signal of their preparation to lead. Notably, the shift eliminates a barrier for entrants from other fields who wish to become school leaders.

In 2012, in response to criticism that the system was too centralized and that the National College did not have the resources to provide adequate leadership training nationally, the National College announced that it would no longer commission leadership development training or limit the number of people who could be trained. It undertook a review of its delivery model and subsequently licensed 33 providers across the nation to deliver the leadership development modules that culminate in national qualifications. The licensees pay a small fee to the central government for use of the National College training materials (which they are expected to use, but report using only to varying degrees). Each licensee is made up of a partnership of a variety of entities in the English system. Partners include universities, non-profit leadership development organizations (including trusts), teaching schools (schools sanctioned to lead other schools), chains of schools (similar to charter management organizations in the U.S.), and for-profit organizations.

The role of the National College shifted again in 2012 when it was brought into the government as an Executive Agency of the Department for Education, which reduced its autonomy to develop leadership policy for the nation. 
Currently, the government often subsidizes demand for the services of the 33 leadership providers across the country. Thus, while schools generally have a professional development budget, many are asked to pay only a portion of the actual cost of leadership development. This creates an attractive incentive for schools to send aspiring leaders to the licensees for leadership training. Although licensees are only three years into the current model, many I interviewed have more demand for their leadership development offerings than they have the capacity to provide. However, this picture of excess demand for leadership training may not represent the entire country, as market reactions may differ in regions where there are fewer school leaders available.

It is also unclear to what extent the current system is building capacity across the nation or whether it is merely leading to more competition for the current supply of leadership talent. Though there are stories in the press about schools having trouble finding qualified leaders, the national figures do not show evidence of a shortage of school principals. According to Greany, now at the Institute of Education at the University of London, salaries for head teachers have gone up at a rate greater than inflation, "which shows there is a war for talent, but its unclear whether this is due to the increasing challenge of the profession or due to a leadership shortage." Since leaders are on school contracts, there is a fair amount of poaching of leaders going on in the system. "So one question is," Greany added, "is more capacity being developed in the system or are schools merely competing for a fixed supply of talent?"

The numbers do suggest, however, that the national qualification, at least for head teachers, has become an important credential for leading a school. Since 1997, according to government figures, approximately 35,000 educators have graduated with the National Professional Qualification for Headship (NPQH), and well over half-around 58\% - of current head teachers hold the NPQH (Gibbs, 2011). Graduates for the 2-year middle leadership and senior leadership programs, initiated in 2012, are just starting to emerge.

In another step toward de-emphasizing the centralized leadership development model in favor of a school-led approach, in 2014 the National College announced that it would stop developing the leadership curriculum, that it would make its curriculum and materials publicly available online in 2016, and that the licenses issued to leadership development providers would be allowed to expire in 2016. The system is moving toward a more horizontal, school-led model, while retaining the more vertical national qualification system. According to Melling of the National College, "The goal is to move to a system where the school system is taking ownership. We are developing our thinking alongside the system to determine the model for delivery beyond 2016. There are challenges in a system where there is a strong appetite for a national benchmark and a national qualification that ensures quality and consistency across the country while also recognizing that there is a diverse marketplace with many routes to training leaders." 


\section{Deepening School and School Leadership Networks}

Major changes in the political environment have profoundly influenced how reformers in England think about leadership development. Conservative Party leader David Cameron became prime minister in 2010 by forming a coalition government with the Liberal Democrats. Since then England has been moving toward "a school-led system." The philosophy behind this movement is that schools, not the central government, should lead capacity building and innovation in the system. Critics call this a cloak for abrogating governmental responsibility for public education.

One of the major changes in England over the past 5 years has been the movement away from schools clustered underneath local authorities (the American equivalent of a school district) to what are called academy schools. An academy is an independent, publicly funded school accountable to the government. Academies operate much like charter schools in the United States; they have freedom from control of the local authority, the ability to set their own pay and employment conditions for staff, freedom from the national curriculum, and the ability to change the lengths of terms and school days. They also take over managerial functions like payroll, budgeting, and plant management. The school landscape in England is composed of a set of individual schools rather than the school district structure common in the United States.

Decentralization has increased both the autonomy and pressure on school leaders, who have more influence over a range of decisions that were previously determined though local authority and governmental strictures. As Peter Earley, a leading scholar on English educational leadership, recently wrote, "the potential increase in school autonomy from local authority governance, through the adoption of academy status or through other clustering arrangements and formal federations, may well place new duties and pressures on school governors" (2012, p. 59). However, other head teachers feel that the freedom is overstated. "In theory, academy status gives you flexibility over your curriculum, the school year, those kinds of things," said one secondary school head teacher I interviewed. "But in reality, because of the examination system which drives the curriculum, we haven't used those so-called freedoms. So, on the ground, I don't think it has made as much difference as the politicians felt it would make."

The shift toward academies, particularly for secondary schools, is marked. Over the last 5 years there has been a stampede of secondary schools converting to academies-now comprising almost 70 percent of all secondary schools in the country. The generally smaller primary schools still tend to find it more cost- 
effective to rely on the centralized management capacity of the local authority, so there have been fewer conversions among lower grade schools.

There are three very different types of academy schools. One is called a converter academy. Converter academies are existing schools that are functioning reasonably well and feel they would benefit from separating from their local authorities (and are provided one-time incentive payments to establish their own management systems) and freely choose to do so. The second type of academy is called a sponsored academy. Sponsored academies are low-performing schools that are pushed to affiliate with sponsoring agencies to assist in performance improvement. Groups of sponsored academies, called academy chains, often privately operated but accountable to the public, are a growing trend in England. Academy chains often have their own themes and educational philosophies, much like KIPP or Imagine schools in the United States. The third type of academy, called free schools, are startups that can be proposed by groups of parents, education charities, or religious groups to initiate a publicly funded school.

A very important implication for leadership development is that several of the largest academy chains are developing their own leadership development curricula that fit their approach to schooling. Several received licenses to become leadership development providers for the national qualifications. And, as the national qualifications become optional, this is causing some concern among policy makers and academies as to whether there will continue to be a commonly accepted set of leadership skills, which they viewed as a main benefit of the National College-led system.

Concomitant with the movement toward academies, the government is strongly pushing for a system of school-led improvement through a network of schools led by a teaching school. Teaching schools are modeled after teaching hospitals, in which an excellent school facilitates the development of other schools. According to a report co-authored by George Berwick, a secondary school head teacher who developed and champions the model:

Teaching schools are the transformative leaders of groups of 25 or more schools that choose to be allied together. They are expected to identify, demonstrate, and disseminate best practices through their role in initial teacher training, the professional development of teachers, leadership development, succession planning, school-to-school support, and research and development to ultimately improve outcomes for children. (Mathews \& Berwick, 2013, p. 5)

In order to be accredited as a teaching school, a school must have an outstanding rating in the nation's school accountability system. Currently about 300 schools have been certified as teaching schools. These schools are leading improvement for 
schools that choose to partner with them, and they hold a very prestigious place in the vanguard of the education system. The government policy goal is to develop 500 teaching school networks in the country, within which both teacher and leadership development is initiated and developed by schools in partnership with their peers.

During my fieldwork in England, I visited Lampton Academy, which converted to an academy school in 2010 and is in the first cohort of teaching schools in the nation. Lampton is an ethnically diverse school of about 1,400 students and 90 teachers located on a quaint campus in a small town west of London, near Heathrow Airport. Most recently inspected in May 2013, Lampton has an Outstanding rating on all categories of the national school evaluation system.

During my visit I met with Dame Sue John, the head teacher of Lampton Academy, and Jacquie Smith, associate head of the Lampton Teaching School. The Lampton Teaching School leads the London West Alliance, a network of 21 primary and secondary schools.

Dame Sue has been the head teacher at Lampton for the past 15 years and has been heavily involved in school reform in London, and nationally, during that time. She is the City Challenge Director of the London Leadership Strategy, a non-profit that provides school-to-school support for London schools; she is also a member of the Future Leaders Trust board and a member of the Department for Education Secondary Headteachers' Reference Group. In 2011, she became a titled dame of the British Empire for her work in education.

According to Dame Sue, the more decentralized reforms of the current government have stimulated significant productive activity. "The current movement has unleashed a huge amount of creativity and innovation. The National College, as it existed before, brought together the research and created some very, very good theoretical and intellectual frameworks for head teachers, which continue to be very important to the work we do. But sometimes they use bureaucracy as a form of control, which has stifled innovation. So there are some very innovative developments of late," she said.

The London West Alliance is more of a collaborative learning network than a formal set of course offerings. It sponsors and facilitates a range of professional learning opportunities for teachers and leaders of the schools in the network, including curriculum development training, skills instruction in the content areas, training of gifted and talented teachers, inclusion strategies, and subject area working groups. 
While these are structured like courses, they are led by Lampton Academy faculty or other faculty members in the London West Alliance. What makes them particularly distinctive is that they are largely generated and delivered by the Alliance members. The Alliance also offers courses in leadership development in areas like succession planning and talent development. Dame Sue runs an ongoing workshop for head teachers in the network.

Funding for the London West Alliance comes from a variety of sources. According to Dame Sue, teaching schools get $£ 40,000$ (about US $\$ 65,000$ ) per year from the government to run the teaching school, but that's not nearly enough to support Smith and another administrator to coordinate and fund the teaching school's programs. Additional funding comes from the participating schools, which pay a fee to join the network. The teaching school also applies for grants to fund initiatives.

According to Smith, what makes the London West Alliance distinctive is the collaborative way the participating schools develop a mutually valuable set of offerings, rather than have Lampton play the role of the solution provider:

We have a team that understands how to get schools to work together in a collaborative way. We understand the complexity of what it means for schools to work together. Second, you need a shared vision. Too often it is perceived to be the ego of the lead school. So one of the things we have tried to do is not to be modeling the ego of the lead school. We say our job is to oil the mechanism, to make it work. If it's all Lampton, that is not a good thing. So we do an amount of vision and pacesetting, just to keep the standards high. The vision for our alliance is that we collectively improve the quality of the learning for the students in our alliance.

This did not mean, she explained, that all the participating schools had equal roles. "In any partnership there will always be stronger and weaker partners. Some have more to give and some have more to receive, and this is why the behaviors are really important. And as people become stronger, they can give more. You need disciplined leadership," she said.

Both Dame Sue and Smith agreed that the teaching school designation is a benefit to Lampton for a range of reasons. Of course, there is the prestige associated with being a teaching school-which also comes with the pressure to maintain its high level of performance in the national accountability system in order to keep its teaching school status. But also there is the benefit of gaining ideas from being exposed to the practices of other schools. "We learn a lot as well as give a lot. We bring a lot of ideas back to the school that we would have never thought about. It is something that we really gain out of the Alliance," explained Smith. This crossgermination is a central idea of the school network concept. Additionally, Smith described the benefit to Lampton's and other schools' teachers of organizing and 
leading professional development. "Teachers, like anyone, like to be seen as doing a good job," explained Smith. "In terms of motivation, they are quite altruisticotherwise they would be in the independent sector. They do want to make a difference to the learning of other professionals. If they work damn hard at something, they want it to be recognized. And this is one of the reasons it really motivates them."

But Dame Sue also recognized the potential pitfalls of the move toward teaching schools. "There are real dangers in this direction as well," she said. "These networks rely on schools to take the initiative to seek partnerships, and there are some who can't help themselves." In addition, schools that are rated as outstanding on the school inspection system, which is a pre-requisite to become a teaching school, are not equally distributed across the country, so some regions have relatively few candidates to lead school networks. Thus, as the Lampton leaders recognized, the school network reform model has the potential to exacerbate inequality.

\section{The Wider Market for Leadership Development in England}

The flourishing market for leadership training in England has been stimulated by at least three forces: (1) the government's attention to leadership (via the high profile work of the National College); (2) the subsidization of the leadership training that leads to the national professional qualifications for middle leaders, senior leaders, and head teachers; and, as I discuss in the next section, (3) the role of leadership in the nation's school accountability system. These forces have contributed to a general belief in the field that the professional development of teachers and leaders is both a pathway to improvement and an incentive for attracting and retaining talented personnel. Most schools set aside funds for staff development, and there are many, largely non-profit, providers who offer training for leaders across the country. Some of these have been directly stimulated by the government, like the Future Leaders Trust, which was partially funded by the National College to provide school head leadership development for schools in challenging contexts, and a companion trust called Teaching Leaders, which focuses on developing middle leaders. These organizations continue to be subsidized directly by the National College to provide leadership development to the poorer schools and regions of the nation. Another type of subsidy is the licensure of the 33 providers of the National College curriculum that leads to the national qualification, because they are the only organizations that can provide this training.

In addition to those organizations sponsored by the government, a number of private entities provide leadership development to schools. One leading group is SSAT, a private limited company that I visited during my fieldwork in England. SSAT offers an array of leadership development courses_-ranging in length from 6 
months to 2 years-for different types of school leaders. Founded in the early 2000s, SSAT worked with David Hargreaves, a prominent leadership scholar in England, to develop a program around what it calls "the four deeps"-deep learning, deep support, deep experience, and deep leadership-which emphasize inquiry, action research, and continuous improvement. "We try to show leaders how they can make innovation work for them," explained Sue Williamson, the chief executive of SSAT. "We try to help leaders be critical and reflective about what they do and why they do it by bringing external thoughts and ideas to them so they think of things in new ways," she said. According to Daniel Belcher, the head of leadership for SSAT, the organization has touched about a third of the secondary schools in England.

Professional associations are another type of leadership provider in England. These include National Primary Heads, for primary school heads, and the Association of School and College Leaders (ASCL), which counts among its membership almost $85 \%$ of the nation's secondary school principals. These organizations host ongoing seminars and professional learning opportunities for their members. According to Brian Lightman, the general secretary of the ASCL, the organization has provided leadership training to over 5,000 of its members as of 2013.

Much like in the United States, a parallel market for leadership development is offered by the England's university system. Practitioners can seek master's and doctoral degrees in educational leadership even while they pursue schoolsponsored training and national qualifications. In fact, several of the current and aspiring school leaders I talked to had university degrees in addition to national qualifications. University programs tend to be more conceptual, focusing on theories and frameworks of leadership rather than on the nuts and bolts of leadership practice. "We have always seen ourselves as providing something different than what is provided by the National College," said Sue Swaffield of the School of Education at Cambridge University, "but we absolutely see ourselves as providing excellent professional development opportunities for aspiring school leaders as well as those already leading schools in a variety of ways." According to education professor Tony Bush, a leading scholar of educational leadership in England, "A significant side-effect of the creation and success of the National College has been a negative impact on universities," which are having more difficulty recruiting candidates and consequently are scaling back their programs. "Many school leaders who might have taken postgraduate degrees now seem to believe that NCSL's less demanding provision is sufficient to meet their need," argued Bush (2008, p. 85). 


\section{The Role of Leadership in School Accountability}

The school accountability system in England has had a major influence on leadership practices in schools. The Office for Standards in Education, Children's Services and Skills (Ofsted), a non-ministerial government department headed by Her Majesty's Chief Inspector of Schools in England, is the linchpin of the English school accountability system. In contrast to the U.S. system, which relies primarily on test scores to produce school performance ratings that are the basis for accountability, England has a more elaborate system of school visits that produces a school rating. These types of school inspection systems are increasingly the rule, rather than the exception, across Europe.

To judge school quality, a team of two to five inspectors (based on school size) performs a 2- to 3-day visit. The inspectors judge the school on three categories: quality of teaching, behavior and safety of pupils, and leadership and management. A fourth category-achievement of pupils based on test performance-is also used to assess a school's quality.

A school's overall rating is a holistic integration of the four categories into an overall judgment on a 4-point scale, as follows:

1. School is outstanding

2. School is good

3. School requires improvement

4. School is inadequate

This parsimonious set of categories (quality of teaching, behavior and safety of pupils, achievement of pupils, and leadership and management) has been winnowed down from earlier eras of inspections, when almost 30 judgments were made. "Politicians have few levers to influence schools, and are tempted to inspect things so people will pay attention. In the old system they were making 27 judgmentssuch as, how much does a school contribute to community cohesion?-but the risk is you take schools away from their core business," explained the National College's Taylor.

The frequency of the inspection of a school depends on its prior rating. Schools with good ratings are generally inspected once every 2-4 years, while schools with lower ratings are inspected more frequently. Schools can be inspected at any time with little advance notice; Ofsted formally notifies a school at noon the day before an inspection. Inspectors typically visit all or most classrooms, talk to students and teachers, and interview the school leaders and members of the school's governing 
board. ${ }^{1}$ The inspection system uses computerized models of risk assessment that might trigger an inspection. Schools might also be inspected if other information comes to light, or due to a rapid decline in student performance data.

A key feature of England's school accountability system is its explicit attention to leadership. Not only is leadership a specific focus of school inspections, but leaders are also seen as accountable for all elements of a school's performance. "We used to have a separate grade for the head teacher. But now the head

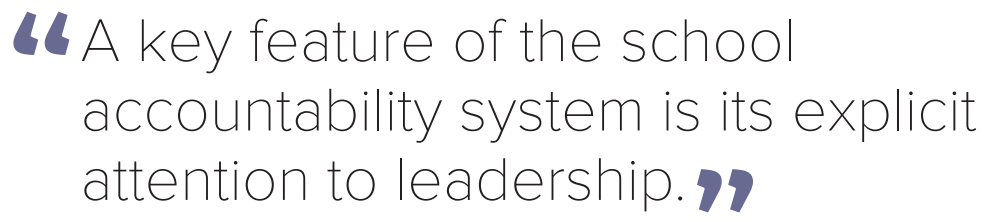
teacher is accountable for all aspects of the school," said Adrian Gray, Ofsted's divisional manager of Challenge and Analysis. According to Ofsted's framework for school inspections:

Inspection examines the impact of all leaders, including those responsible for governance, and evaluates how efficiently and effectively the school is managed. In particular, inspection focuses on how effectively leadership and management at all levels promote improved teaching, as judged within the context of the school, and enable all pupils to overcome specific barriers to learning. (Ofsted, 2014)

The emphasis on instructional leadership at the different leadership levels is particularly noteworthy.

A particularly contentious topic is whether Ofsted has a specific view of teaching. The official Ofsted position focuses on learning. According to Gray, "Our approach to teaching is 'does it promote learning?' If it promotes learning, that is fine. If it doesn't promote learning, that is not fine. And we don't define how you should do it. So the inspector will go into the lesson, and the focus should be on pupils, not on the teacher. Are the students learning well? So we are trying to get people to understand that we are not evaluating teaching, we are actually evaluating learning." This approach focuses both the inspector and the teacher on the students' attention and behavior. As Gray notes, “Just by observing the lesson you can't judge the lesson, you need to talk to the pupils. If I am in the lesson, I can observe who is stuck and who is finished early, all those things you can't judge by watching the teacher."

The accountability system in England is very distinct from that of the United States. While the U.S. focuses primarily on "harder" measures of student performance as

1 Every school has a governing board of local community members who typically focus on setting the vision for the school, holding the headmaster accountable for student performance, and supervising the fiscal management of the school. 
the indicator of school quality, the English system incorporates "softer" measures collected during school inspections. A recent, rigorous study of the English inspection system (Hussain, 2012) found that schools that were rated "poor" in their inspection made substantial test score progress following their failed inspection and that student gains persisted even after students matriculated from the lowrated school, "which is consistent with the notion that teachers inculcate real learning, not just test-taking skills in response to a fail rating," (Hussain, p. 4). Further, Hussain found that schools improved without resorting to the kind of gaming behaviors - targeting students on the margin or excluding low ability students from the test taking pool - that researchers have found in the United States (Hamilton, 2003). Additionally, schools that failed inspections increased their emphasis on student discipline and did not have higher levels of teacher turnover. These findings suggest that an inspection-based accountability system may have fewer negative consequences than a test-based accountability system because the signals are broader and more aligned with the larger system goals.

Pressure is in the eye of the beholder, and schools in England seemed just as pressed by accountability as they do here in the United States. "I've been working in schools for 30 years," explained one school leader I interviewed, "and I've never experienced a time when you were expected to produce results so rapidly with so little time to prepare. And now more than ever we should be investing in finding out if what we are doing is wasting our time. But the culture of teaching has been one of 'do,' just get on with it and do it, and not reflect on what we are doing, so schools just do a whole bunch of different initiatives hoping something will work."

\section{Distilling the Elements of the Leadership Lattice}

As experienced weavers well know, the best tapestries are the result of skillfully entwining the warp and the weft. England's recent efforts to develop stronger school leadership capacity similarly contain both vertical and horizontal strands that form the lattice for school leadership.

The effort began with a centrally led effort to introduce a hierarchy of school leadership into the essentially flat organizational structure of schools by articulating and professionalizing leadership responsibilities at multiple levels within schools. Across a span of 15 years, leadership development in England went from a primary focus on a single leader (the head teacher) to an emphasis on a nested team of leaders, each with individual roles and responsibilities, but all working in concert toward sustained school improvement. The development of this hierarchy of leadership arose from the following key elements: 
- The vision of a system of school leadership, developed by the quasigovernmental National College for School Leadership, that articulated the roles and responsibilities of various levels of leadership. This included a principal overseeing and leading the school's efforts, working in concert with a senior leadership team, in combination with a set of middle leaders specifically charged with overseeing subject areas or grade groups, working with, and accountable for, the instructional performance and developmental needs of a set of teachers and students. Defining the responsibilities of middle leaders was particularly distinctive because it identified professionals who, because they work closely with teachers, can more closely foster and monitor individual teachers' improvement.

- The identification of an explicit set of knowledge and skills for leaders to develop, which was codified in a curriculum and sophisticated set of professional learning experiences for leaders at each level, culminating in a credential in the form of a national qualification. The national qualification served as both a signaling system and a nationally consistent benchmark for quality.

- The prioritization of leadership as an essential element of school improvement was supported by substantial investments both to encourage schools to develop their leaders and to infuse this vision of leadership into the regular routines and practices of schools. To date the effort has produced a robust and growing cadre of school leaders who hold the leadership qualifications, particularly at the headship level. Perhaps even more importantly, the vision of a hierarchy of school leadership is becoming ensconced in the structure of English schooling, particularly at the secondary level.

- Finally, and crucially, this vision of leadership is aligned with and incorporated into other aspects of the educational structure. Most vitally, it is integrated into the nation's school accountability system, where leadership is one of the four essential criteria for school quality, and leaders are viewed as responsible for all four judgment categories.

Since 2010, with the transition from the Blair to the Cameron government, leadership development has moved toward a flatter structure of markets and networks for school leadership. Though fledgling and less defined, this system features: 
- The movement toward a more decentralized market for leadership development. In 2012, the National College transitioned from direct delivery of leadership development to the licensing of regional groups of certified school-centered providers to deliver its leadership curriculum. The stated intention is to let these licenses expire in 2016, at which time the leadership curriculum will enter the public domain and leadership services will transfer to a non-governmental body or become more market-based. In either case, the government's role will diminish over time.

- A shift of the National Professional Qualification for Headship (NPQH) from a required to an optional leadership certification. The argument for making the national qualification optional rather than required is that a high-quality, aspirational qualification is a stronger signal than a required certification. In theory, this also allows for a more diverse range of leaders to enter education laterally and become school leaders, but to date there have been very few cases of successful leaders from other fields becoming school heads. At this time, the practical effect of this shift is unclear.

- Finally, and perhaps most intriguingly, the transition to school-led network of both teacher and leader development, in which groups of schools, led by teaching schools, work within networks on ongoing school improvement. This has the advantages of having learning opportunities emanate from real school need, grounding learning in the challenges of educator practice, and making development more localized, ongoing, and sustained.

This lattice for school leadership development - the integration of a clearly defined set of competencies and aligned training for the hierarchy of leadership positions within schools, as well as a web of school leaders networked for ongoing and grounded development-in many ways surpasses the elements of the framework of talent management I used earlier in the setup for this report. While the talent development framework focuses on the experiences of individual actors, a lattice framework more richly emphasizes both the structures that supply and support current and future leaders' experiences as well as how this leadership development system is integrated into the larger educational system. The lattice concept challenges us to move beyond a linear sequence of tidy steps to support leaders toward a more complex set of interdependent, mutually reinforcing activities initiated and supported at multiple levels across the educational system. 


\section{Discussion}

One of the maddening things about policy reform in democratic societies is that initiatives that appear to be promising often become premature casualties of the pendulum of political change. These changes can come in the wake of shifting political philosophies, as liberal and conservative governments succeed one another. Other times, it is just the transition from one regime to another. It is well established that politicians get more attention and credit for initiating reforms than they do for sustaining those of their predecessors (see Hess, 1998, for an incisive description of this phenomenon). In this vein, it is reasonable to ask if the accomplishments of the National College, largely completed under the Blair government, will be wholly dismantled as a consequence of the philosophy of the more conservative Cameron government, with its propensity toward markets and school-led reform.

Rather than substituting one approach with another, it is sometimes more productive to think of system reform as an evolutionary process whereby one reform sets the stage for additional efforts that can complement those that came before it. For example, without instilling in the landscape leadership pathways for middle leaders and senior leaders as well as head teachers, and defining the knowledge and skills for each of these positions, the lateral networks would not hold nearly as much promise.

Both the hierarchical and lateral approaches to school leadership development have their logic and limitations. The centrally based initiative of the National College brought together talented thinkers to devise a well thought-out and powerful curriculum, but its pre-defined structure often produced a one-size-fits-all experience that, while ameliorated by more flexible elements like coaching, was still distant from everyday practice and often misaligned with individual need. Further, as the curriculum was first licensed and now is seemingly destined to enter the public domain, there are real questions about quality control and whether it will continue to fulfill its feature as a 'national' system.

The lateral approach embodied in the teaching school network has the potential advantage of being more closely aligned with the challenges of practitioners and more responsive to contextual issues. Yet it runs the risk of distracting practicing leaders from their central mission of improving teaching and learning in their own schools, carrying them beyond their expertise, and exacerbating inequities across the system. England's challenge moving forward is to resist abandoning one strand for the other, and evolve toward integrating the best of both approaches, while similarly compensating for their limitations. Each approach is strengthened by the presence of the other. 
Regardless of the eventual state of the leadership development system in England, transferring ideas across contexts, much less oceans, is a tricky business. It would be a mistake to think that something that is fruitful in England would necessarily work in the United States. In fact, many of America's education strategies seem driven by the sheer scale of our national challenge. While historically we have had a predilection for decentralization, a lot of dissatisfaction with our educational performance seems to come from the variable quality that is a consequence of our system of local control. As we seek continuous improvement, it is worthwhile to think about what lessons we might learn from England's efforts to improve its leadership system.

The indelible takeaway from my examination of the English education system is the set of clearly defined leadership responsibilities at different levels that have been instituted into English schools, as well as the accompanying career ladder for school leaders. By contrast, the flat structure of the U.S. educational leadership development and professional learning process appears anachronistic and ill-suited to today's educational challenges. Historically, as laid out earlier in this report, American education has filled school leadership positions beyond the principal and his or her assistant with a patchwork of poorly defined roles and vague positions, typified by generally isolated and under-utilized department chairs and informal teacher leaders without clear responsibilities and authority to influence the practice of other teachers. There is a lack of clarity and tremendous variation in how these roles fit into an individual school's system for improvement of teaching and learning. English policy makers have done yeoman's work in defining the roles of different leadership positions within schools, and we would be wise to examine their system and consider adapting some of its central features.

Formalizing a leadership structure within schools is an idea with merit, but it forces us to consider at least three implementation questions: First, how do you develop the capacity - the knowledge and skills — of people to carry out these roles? Second, how do you motivate people to take on these positions? And finally, how do you ensure that people fulfill their responsibilities?

The strategy for developing schools leaders' capacity is where the philosophical differences among English policy makers came into play. The first group embarked on a strategy to develop a structured set of professional development experiences in order to build school leader capacity. Subsequent reformers have relied on a more market-based approach, transferring leadership development responsibilities to a broad array of providers who are responding more directly to school needs. It is the integration of these two approaches, rather than the layering of one over the other, that holds much promise. 
Government can stimulate demand for building leadership capacity in several ways, many of which were tried in England. It can directly subsidize the cost. It can create a leadership skills

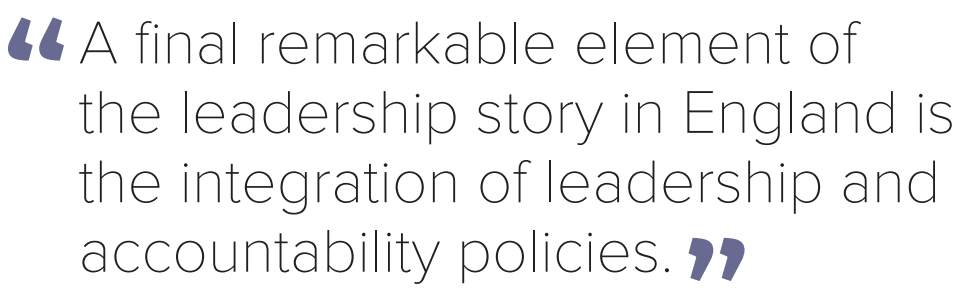
certification that is at least desired, if not required. Or it can link leadership directly to an accountability system to make the connection between leadership and school quality explicit. The system developed in England has an admirable elegance in the way these elements are integrated with and reinforce each other. Note how these efforts align with the three implementation questions raised above.

A final remarkable element of the leadership story in England is the integration of leadership and accountability policies. By making leadership performance at the different school levels an explicit component of a school accountability review, and thereby signaling the importance of these functions, policy makers focused attention on the means of improvement, not just the ends. By contrast, when we look at the evolution of accountability in the U.S., it has been a particularly blunt instrument focused almost exclusively on test outcomes. Even if we agree that test results are the appropriate measure of school quality, a test-based accountability system provides no signals as to what factors schools should attend to in order to achieve high test performance. We may say that this is purposeful, because we care only about outputs and not about inputs, but the last 20 years of test-based accountability have shown that, in the absence of broader signals, or at least counterbalancing guidance, school responses can be unhealthy, leading to narrowing of the curriculum, excessive test preparation, and even downright cheating. In the evolution of accountability policy, the outcome-based accountability systems of the late 1980s were a meaningful transition from the previous emphasis on inputs like seat time, course taking, and attendance. The NCLB shifts toward decomposing performance so that inequities could not hide behind overall averages were also useful. But it should now be clear that accountability is not just a monitoring device-it is also a powerful signaling system that shapes a variety of behaviors. And focusing primarily on test performance attenuates the usefulness of the signals that accountability press can send to educational practitioners. This is an important lesson for state and local educators as they consider the most recent trends toward multi-indicator accountability systems.

The story of leadership development in England shows that the evolution of meaningful reform is not a linear, predetermined process, but rather an emergent and evolving experience that is vulnerable to unpredictable political oscillations. Even so, the English experience holds within it a series of essential questions for those who seek to improve the school leadership system in America: 
- What is the appropriate level of the education system (e.g., state, regional, district, national) to organize leadership-focused reform efforts and align and hold responsibility for integrating leadership policies with other system components (e.g., certification, accountability)?

- What organizations or agencies (e.g., government agencies, universities, professional organizations) could serve in a role akin to the National College of Teaching and Leadership to design leadership roles, formalize knowledge of practice, devise approaches to professional development, and organize networks of schools and school leaders?

- What resources and incentives would support the development of these organizations and agencies and motivate school and system leaders to access their services and opportunities for social exchange?

- What is the proper sequencing and integration between the elements of the two approaches that make up the leadership lattice (e.g., centralized and decentralized structures; academic and craft knowledge; formal and social learning approaches) such that the components build upon and reinforce one another?

- What system of learning can we put into place to help develop a deeper understanding of how these two approaches can be viewed as complementary and synergistic strategies rather than competing and mutually exclusive?

- How might accountability systems incorporate leadership, teaching, and other essential school elements so that they broaden signals to encompass the important components that produce learning outcomes for students rather than narrowing them to focus on student outcomes alone?

- And how could all of these things be done so as to reduce inequalities of educational opportunity-so that the system meets the needs of school leaders at the different places in their development?

Almost every story of school improvement, whether anecdotal or evaluative, cites the importance of leadership. This overwhelming evidence suggests that any systematic strategy for educational improvement necessitates more attention to the essential role of multiple levels of leadership in schools. The American system would benefit from a formal expansion of leadership positions in schools from the traditional reliance on a strong single actor with a weak supporting cast toward a more deliberately integrated system of school leadership. The story of England's leadership development system is an instructive case of how to use the levers of policy to create a vision for school leadership, expand and formalize leadership 
pathways within schools, formulate models to build leadership capacity, attend to incentives to stimulate demand, and carefully push on the right pressure points to constructively focus schools on the important role of leadership in the improvement of teaching and learning. In taking these steps, the English have enmeshed school leadership into the center of school improvement. 


\section{Epilogue}

As I wrap-up this report, the role of the National College in leadership development is in flux. It's clear that its position as a central leadership curriculum designer is ending. When the existing curriculum enters the public domain in 2016, it is uncertain who will broker its use for the national good and whether this element of the lattice will continue to receive support. Thus, at least in the short run, the school networks, or horizontal component of the lattice, will likely gain increasing emphasis.

On a final note, when I received comments back from Kelly Robertson, about whose school circumstance and leadership efforts I started this report, she wrote to me that:

You may also wish to know that we were inspected again at the beginning of July [2014] and our latest Ofsted report is publically available from today. It states that we have moved out of special measures and into requiring improvement. This is a huge relief for us all here and means we can continue to move forward in making rapid improvements for our pupils. [Personal Communication, September 8, 2014].

A tangible victory for the champions of school improvement and all who work so hard to support it. 


\section{A few words about data and analysis}

The idea for this report came from an October 2013 conversation with the Thomas B. Fordham Institute, which was interested in doing an examination of leadership development in the United Kingdom, based on the U.K.'s well-regarded system and the difficulties in the United States of recruiting, developing, and retaining high quality principals. At the time, I knew very little about leadership development in the United Kingdom.

My CPRE colleague Bobbi Newman and I began collecting background information on the education systems of the England, Scotland, Wales, and Northern Ireland, the countries comprising the United Kingdom. We quickly realized that there were many important differences across these systems, both generally and specifically about leadership development and we decided to narrow the focus to England.

We spent four months familiarizing ourselves with the leadership system in England and the education context that surrounded it. This included web searches, background reading, and five background interviews with colleagues from schools of education in English universities. We also settled upon the talent management framework as the conceptual model to guide interview protocols and data collection.

In March 2014, I spent a week in London, visiting schools and offices and attending half a day at a conference of the British Educational Leadership Management and Administration Society (BELMAS), which focused on the teaching school model. During the site visit, I interviewed 17 people, including teachers and school leaders, government officials, university researchers, union officials, and leadership providers. These interviews were audio-recorded, and I immediately began to take close notes from the recordings while they were fresh in my mind.

Through what I experienced from the site visit and my analysis of the interviews, the two key elements of England's leadership development-the curriculum of the National College and the teaching school model-began to emerge as the main strands of the work, and my write-up of the system began to shift from an emphasis on the elements of the talent development system to the two components of the lattice for school leadership.

Once a draft was complete, I sent it to those whom I interviewed to give them the opportunity to both confirm the accuracy of my interpretations and their quotes. I also sent the report to several colleagues for comment and feedback; this process helped me to sharpen and distill my themes. 


\section{References}

Berger, L. A., \& Berger, D. R. (2011). The talent management handbook: Creating a sustainable competitive advantage by selecting, developing, and promoting the best people. New York, NY: McGraw-Hill.

Bush, T. (2008). Leadership and management development in education. London, England: Sage Publications.

Cappelli, P. (2008). Talent on demand. Boston, MA: Harvard Business School Publishing.

Collins, J. (2001). Good to great: Why some companies make the leap... and others don't. New York, NY: HarperCollins Publishers.

Earley, P. (2013). Exploring the school leadership landscape: Changing demands, changing realities. London, England: Bloomsbury Publishing.

Gibb, N. (2011, December). Overhaul of headteachers' qualification to help train the next generation of great school leaders. Retrieved from: https://www.gov.uk/ government/news/overhaul-of-headteachers-qualification-to-help-train-the-nextgeneration-of-great-school-leaders

Hallinger, P. (2003). Leading educational change: Reflections on the practice of instructional and transformational leadership. Cambridge Journal of Education, 33(3), 329-352.

Hallinger, P., \& Heck, R. H. (1998). Exploring the Pprincipal's contribution to school effectiveness: 1980-1995. School Effectiveness and School Improvement, 9(2), 157-191.

Hamilton, L. (2003). Assessment as a policy tool. Review of Research in Education, 27, 25-68.

Hargreaves, A. P., \& Shirley, D. L. (Eds.). (2009). The fourth way: The inspiring future for educational change. Corwin Press.

Hargreaves, A., Boyle, A., \& Harris, A. (2014). Uplifting leadership: How organizations, teams, and communities raise performance. John Wiley \& Sons.

Hess, F. M. (1998). Spinning wheels: The politics of urban school reform. Washington, DC: Brookings Institution Press.

Hussain, I. (2012). Subjective performance evaluation in the public sector: Evidence from school inspections (Report CEE DP 135). London, England: Center for Economic Performance, London School of Economics. 
Leithwood, K., \& Jantzi, D. (2000). The effects of transformational leadership on organizational conditions and student engagement with school. Journal of Educational Administration, 38(2), 112-129.

Leithwood, K., Seashore Louis, K., Anderson, S., \& Wahlstrom, K. (2004). Review of research: How leadership influences student learning. New York, NY: Wallace Foundation.

Mangin, M. M., \& Stoelinga, S. R. (2009). The future of instructional teacher leader roles. The Educational Forum, 74(1), 49-62.

Mathews, P. \& Berwick, G. (2013). Teaching schools: First among equals? Nottingham, England: National College for Teaching and Leadership.

Ofsted, The Office for Standards in Education, Children's Services and Skills. (2014). Framework for school inspection. Manchester, England. Retrieved from http://www. ofsted.gov.uk/resources/framework-for-school-inspection

Schleicher, A. (Ed). (2012). Preparing teachers and developing school leaders for the 21st century: Lessons from around the world. Paris: OECD Publishing.

Silins, H. C. (1994). The relationship between transformational and transactional leadership and school improvement outcomes. School Effectiveness and School Improvement, 5(3), 272-298.

Spillane, J.P. (2006). Distributed Leadership. Jossey-Bass: San Francisco, CA.

Supovitz, J. A. (2008). Instructional leadership in American high schools. In M. M. Mangin \& S. R. Stoelinga (Eds.), Effective teacher leadership: Using research to inform and reform (pp. 144-162). New York: Teachers College Press.

Supovitz, J. A. \& Riggan, M. (2012). Building a foundation for school leadership: An evaluation of the Annenberg Distributed Leadership Project, 2006-2011. (Report RR 75). Philadelphia, PA: Consortium for Policy Research in Education.

Supovitz, J. A., \& Tognatta, N. (2013). The impact of distributed leadership on collaborative team decisionmaking. Leadership and Policy in Schools, 12(2), 101-121.

Turnbull, B. J., Riley, D. L., Arcaira, E. R., Anderson, L. M., \& MacFarlane, J. R. (2013). Six districts begin the principal pipeline initiative. New York, NY: Wallace Foundation.

Van Meter, E., \& Murphy, J. (1997). Using ISLLC standards to strengthen preparation programs in school administration. Washington, DC: Council of Chief State School Officers.

York-Barr, J., \& Duke, K. (2004). What do we know about teacher leadership? Findings from two decades of scholarship. Review of Educational Research, 74(3), 255-316.

Wolcott, H. (1974). The man in the principal's office: An ethnography. Walnut Creek, CA: Altamira. 